\title{
Role of Nicotinamide Adenine Dinucleotide and Adenosine Triphosphate in Glucocorticoid-induced Cytotoxicity in Susceptible Lymphoid Cells
}

\author{
Nathan A. Berger, Sosamma J. Berger, Donna C. Sudar, and Clark W. Distelhorst \\ Hematology/Oncology Division, Departments of Medicine and Biochemistry, Case Western Reserve University School of Medicine; \\ $R$. Livingston Ireland Cancer Center and University Hospitals of Cleveland, Cleveland, Ohio 44106
}

\begin{abstract}
The possibility that corticosteroid cytotoxicity could be mediated by activation of poly(ADP-ribose) polymerase and consequent depletion of NAD and ATP was evaluated in steroid-sensitive S49.1 and steroid-resistant S49.143R mouse lymphoma cells and in lymphocytes from a patient with chronic lymphocytic leukemia. All cell types were shown to have the enzyme poly(ADPribose) polymerase and to increase activity in response to DNA strand breaks. Incubation of susceptible cells with $1 \mu \mathrm{M}$ dexamethasone resulted in DNA strand breaks. Susceptible cells also showed a dose-dependent decrease in NAD and ATP that preceded loss of cell viability. These studies suggest that steroidinduced cytotoxicity in susceptible lymphocytes is due to the presence of DNA strand breaks that activate poly(ADP-ribose) polymerase to a sufficient degree to consume cellular pools of NAD with a consequent depletion of ATP and loss of cell viability.
\end{abstract}

\section{Introduction}

Corticosteroid-induced cytotoxicity in lymphoid cells requires initial binding of the steroid to a cytoplasmic receptor, which then undergoes translocation to the nucleus and binding to chromatin $(1,2)$. The subsequent steps in corticosteroid-induced cytotoxicity have not been clearly defined. However, several reports indicate that in susceptible cells, corticosteroids induce DNA strand breaks and chromatin fragmentation $(3,4)$.

We have recently shown that activation of the chromosomal enzyme poly(ADP-ribose) polymerase by DNA strand breaks can initiate a pathway of metabolic alterations that leads to cell death as an indirect consequence of DNA damage $(5,6)$. Most cells contain poly(ADP-ribose) polymerase in a reserve inactive form (7). Upon activation by DNA strand breaks, the enzyme cleaves $\mathrm{NAD}^{+}$at the glycosylic bond between the nicotinamide and adenosine diphosphoribose portion of the molecule. The latter moiety is covalently linked to macromolecular acceptors, and subsequent residues are covalently linked by $O$-glycosidic linkages to form homopolymers of adenosine diphosphoribose (8). In the presence of extensive or persistent DNA strand breaks, poly(ADP-ribose) polymerase can be activated to consume cellular pools of its substrate, NAD. The decrease in NAD leads to a consequent fall in ATP with associated dire consequences for the cell $(6,7)$. As a result of the ultimate depletion of NAD

Received for publication 4 August 1986 and in revised form 9 December 1986.

J. Clin. Invest.

(c) The American Society for Clinical Investigation, Inc.

0021-9738/87/06/1558/06 \$1.00

Volume 79, June 1987, 1558-1563 and ATP, cells undergo drastic changes in carbohydrate metabolism (9), lose their ability to conduct energy dependent functions such as DNA/RNA protein synthesis, and subsequently die (5, $6,9)$. The present studies were carried out to analyze the induction of DNA strand breaks by corticosteroids and the consequences on NAD and ATP metabolism in steroid-susceptible and -resistant lymphoid cells.

\section{Methods}

The steroid-sensitive S49.1 and steroid-resistant S49.143R mouse lymphoma cells have been described previously $(1,2,10)$. They were grown in suspension culture at $37^{\circ} \mathrm{C}, 8 \% \mathrm{CO}_{2}$ in Dulbecco's modified Eagle's medium supplemented with $10 \%$ heat-inactivated fetal calf serum (FCS), $20 \mathrm{mM}$ glutamine, $50 \mathrm{U} / \mathrm{ml}$ penicillin, $50 \mu \mathrm{g} / \mathrm{ml}$ streptomycin, $0.1 \mathrm{mM}$ nonessential amino acids (M. A. Bioproducts, Walkersville, MD). Lymphocytes from normal human donors and patients with chronic lymphocytic leukemia (CLL) ${ }^{1}$ were prepared from peripheral blood by defibrination, Ficoll-Hypaque gradient centrifugation, and monocyte removal by plastic absorption, as previously described (11). Cells were incubated at 3-5 $\times 10^{6} \mathrm{cells} / \mathrm{ml}$ at $37^{\circ} \mathrm{C}$ in $\alpha$-modified Eagle's medium supplemented with $10 \%$ heat-inactivated FCS, $50 \mathrm{U} / \mathrm{ml}$ penicillin, 50 $\mu \mathrm{g} / \mathrm{ml}$ streptomycin, and $25 \mathrm{mM}$ Hepes, $\mathrm{pH}$ 7.2. Cells were treated with the indicated concentrations of dexamethasone, purchased from Sigma Chemical Co., St. Louis, MO, as 9- $\alpha$-fluoro-16- $\alpha$-methyl prednisolone irradiated for use in aseptic procedures. Cell viability was determined by trypan blue exclusion.

Poly(ADP-ribose) polymerase activity was determined in cells rendered permeable to exogenously supplied nucleotides, as previously described $(7,11)$. The assay system for basal measurements of poly(ADPribose) polymerase activity contained $33 \mathrm{mM}$ Tris- $\mathrm{HCl}, \mathrm{pH} 7.8,20 \mathrm{mM}$ mercaptoethanol, $0.6 \mathrm{mM}$ EDTA, $2.6 \mathrm{mM} \mathrm{MgCl}, 0.33 \mathrm{mM}$ [adenine $\left.2,8-{ }^{3} \mathrm{H}\right] \mathrm{NAD}^{+}\left(\mathrm{sp}\right.$ act, $\left.20 \times 10^{3} \mathrm{dpm} / \mathrm{nmol}\right)$, and $1 \times 10^{6}$ permeabilized cells in $75 \mu$ l. The reaction system to measure maximally stimulated levels of poly(ADP-ribose) synthesis contained the same components and was adjusted to a final concentration of $0.05 \%$ Triton X-100 and a total of $100 \mu \mathrm{g}$ DNAse I (10). Incubations were at $37^{\circ} \mathrm{C}$ for $30 \mathrm{~min}$ and were terminated by adding an excess of $10 \%$ TCA, $2 \% \mathrm{Na}_{4} \mathrm{P}_{2} \mathrm{O}_{7}$. Precipitates were collected on glass fiber (GF/C) filters and processed for counting as previously described $(7,11)$.

For measurements of $\mathrm{NAD}^{+}$and ATP, cells were collected by centrifugation at $3,000 \mathrm{~g}$ at $4^{\circ} \mathrm{C}$ for $3 \mathrm{~min}$, and acid extracts were prepared with $0.35 \mathrm{~N} \mathrm{HClO}_{4}$ and neutralized with $2.1 \mathrm{M} \mathrm{KOH}, 1 \mathrm{M}$ imidazole base, and $0.5 \mathrm{M} \mathrm{KCl}$. Nucleotides in the cellular extracts were measured by enzymatic cycling techniques as previously described $(5,12)$.

For elutriation experiments, cells were centrifuged at $650 \mathrm{~g}$ for 10 min and resuspended in $10 \mathrm{ml}$ phosphate-buffered saline (PBS), $1 \mathrm{mM}$ EDTA, and $2 \%$ FCS at pH 7.2. Elutriation was performed with a model J-6M centrifuge equipped with an elutriation rotor (Beckman Instruments, Inc., Fullerton, CA). Cells were loaded into the elutriation chamber at a rate of $7 \mathrm{ml} / \mathrm{min}$ with a Masterflex peristaltic pump (model 7014.20; Cole-Parmer Instrument Co., Chicago, IL). Rotor speed was maintained

1. Abbreviations used in this paper: ADPR, adenosine diphosphoribose; CLL, chronic lymphocytic leukemia. 
at $1,600 \mathrm{rpm}$ at $25^{\circ} \mathrm{C}$ throughout the experiment. 100 -ml fractions were eluted by stepwise $2 \mathrm{ml} / \mathrm{min}$ increases of the flow rate of PBS/EDTA/ FCS through the rotor. Viable cells remaining in the chamber after collection of three fractions were eluted at a rate of $24 \mathrm{ml} / \mathrm{min}$.

DNA strand breaks were measured by the alkaline elution method modified for fluorescent analysis of DNA fractions in nonlabeled cells $(13,14)$. After incubation with or without dexamethasone, cells were collected by centrifugation at $100 \mathrm{~g}$ for $10 \mathrm{~min}$ and resuspended in PBS, pH 7.5, at a concentration of $8 \times 10^{6} / \mathrm{ml} .8 \times 10^{6}$ cells were deposited on a $47-\mathrm{mm}$ diameter polycarbonate filter (Nucleopore Corp., Pleasanton, CA) $8-\mu \mathrm{m}$ pore size and washed with PBS, pH 7.5. Cells on the filter were lysed in the dark with $10 \mathrm{ml}$ of lyse solution $(2 \mathrm{M} \mathrm{NaCl}, 0.2 \%$ Sarkosyl, $0.04 \mathrm{~N} \mathrm{Na}_{2}$ EDTA, pH 10.0) followed by treatment with 0.5 $\mathrm{mg} / \mathrm{ml}$ proteinase $\mathrm{K}$ (E. Merck, Darmstadt, FRG). Cells were washed again and DNA was eluted from filters at a rate of $0.04 \mathrm{ml} / \mathrm{min}$ with a minipulse-2 peristaltic pump (Gilson Medical Electronics, Inc., Middleton, WI) with $2 \%$ tetrapropyl ammonium hydroxide (Eastman Kodak Co., Rochester, NY), 0.02 M EDTA, pH 12.1, for 15 h (10-90-min fractions were collected). At the end of the elution, filters were removed from filter holders, minced, and incubated in $5 \mathrm{ml}$ of tetrapropyl ammonium hydroxide for $1 \mathrm{~h}$ at $65^{\circ} \mathrm{C}$. Filter holders were washed with 5 $\mathrm{ml}$ of tetrapropyl ammonium hydroxide and combined with eluting buffer remaining in the tubing. The filter holders and tubing were washed with $10 \mathrm{ml}, 0.4 \mathrm{~N} \mathrm{NaOH}$.

For fluorescent assays of DNA concentration, the volume of each fraction was measured and $1 \mathrm{ml}$ was removed from filter, tubing, and final washes as well as from each elution fraction and transferred to 16 $\times 100-\mathrm{mm}$ borosilicate tubes. $0.4 \mathrm{ml}$ of $0.2 \mathrm{~N} \mathrm{KH}_{2} \mathrm{PO}_{4}$ was added to each tube followed by addition of $0.6 \mathrm{ml}$ water. $1 \mathrm{ml} 1.5 \times 10^{-6} \mathrm{M}$ Hoechst dye 33258 (Calbiochem-Behring Corp., La Jolla, CA) in standard saline citrate, $\mathrm{pH} 7.0$, was added before reading samples on a FluorometerA4 excitation $360 \mathrm{~nm}$, emission $450 \mathrm{~nm}$ (Farrand Optical Co., Inc., Valhalla, NY). DNA was quantitated comparison with the fluorescence of standards of calf thymus DNA assayed over a range of 0 to $15 \mu \mathrm{g}$. All samples were assayed in duplicate.

The effect of dexamethasone treatment on DNA integrity was determined by comparing the DNA content remaining on the filters after $15 \mathrm{~h}$ of elution from treated cells with the same measurement performed in nontreated control cells. DNA damage was converted to rad equivalents of gamma radiation by comparison with a standard curve constructed from $L 1210$ cells treated with increasing doses of gamma irradiation and then processed by the same alkaline elution technique.

\section{Results}

Table I shows the results of measuring poly(ADP-ribose) polymerase activity in mouse and human lymphocytes. The basal activity is measured in permeabilized cells treated with gentle conditions to avoid DNA damage, so as not to activate any reserve enzyme $(7,11)$. The DNAse-responsive enzyme activity is measured after treating permeabilized cells with saturating concentrations of DNAse to produce maximum DNA damage so as to activate all reserve enzymes and provide an estimate of the maximum activity that can be generated in response to DNA damage $(7,11)$. The mouse lymphocytes showed higher activity than the human cells. This is the usual pattern for cycling vs. noncycling cells $(11,15)$. The CLL cells had higher activity than the resting human lymphocytes as previously noted (11). All of the cells showed an increase in activity following treatment with DNAse. Thus, mouse line $\mathbf{S 4 9 . 1}$ which is sensitive to corticosteroid induced cell killing and S49.143R which is not, each showed increased poly(ADP-ribose) polymerase activity in response to DNA damage. Similarly, both normal and CLL human lymphocytes showed an increase in poly(ADP-ribose) polymerase activity in response to treatment of cells with DNAse.
Table I. Poly(ADP-Ribose) Polymerase Activity in Mouse and Human Lymphocytes

\begin{tabular}{lll}
\hline & \multicolumn{2}{l}{$\begin{array}{l}\text { Incorporation } \\
\text { cells }\end{array}$} \\
\cline { 2 - 3 } & Basal & DNAse responsive \\
\hline Mouse lymphocytes & & \\
S49.1 & 1,380 & 22,700 \\
S49.143R & 3,250 & 34,700 \\
Human lymphocytes & & \\
Normal & 360 & 3,200 \\
CLL & 820 & 8,400 \\
\end{tabular}

Mouse lymphocytes were maintained in logarithmic growth in tissue culture. Human lymphocytes were freshly prepared from peripheral blood as indicated in Methods. Cells were permeabilized and incubated with $\left[{ }^{3} \mathrm{H}\right] \mathrm{NAD}$ for $30 \mathrm{~min}$ at $37^{\circ} \mathrm{C}$ and then assayed for incorporation of $\left[{ }^{3} \mathrm{H}\right]$ ADPR into poly(ADP-ribose) as indicated in Methods. Basal activity was measured in the absence of DNAse I, whereas the DNAse-responsive activity was measured in the presence of $100 \mu \mathrm{g}$ DNAse I. All values are the means of assays performed in triplicate with $<10 \%$ variation between assays.

We next used alkaline elution to evaluate the effects of corticosteroids on DNA integrity in steroid-sensitive and resistant mouse lymphoma cells. Table II shows that the S49.1 steroidsensitive cells maintained the integrity of their DNA during a 42-h incubation period in the absence of steroids. In contrast, when the S49.1 cells were incubated in the presence of $1 \mu \mathrm{M}$ dexamethasone they began to develop DNA strand breaks as early as $24 \mathrm{~h}$, reaching the equivalent of 270 rad gamma radiation after $42 \mathrm{~h}$ incubation. While the DNA strand breaks induced by the steroids are equivalent to small doses of radiation, it must be remembered that the radiation breaks can be rapidly repaired (16), whereas constant exposure to steroids renders the breaks persistent and cumulative (4).

Table III shows the alterations that occur in NAD levels in sensitive and resistant cell lines treated with $1 \mu \mathrm{M}$ dexamethasone. In the steroid-sensitive S49.1 cell line, treatment for $48 \mathrm{~h}$

Table II. Glucocorticoid-induced DNA Strand Breaks in Mouse Lymphocytes

\begin{tabular}{lllc}
\hline & & \multicolumn{2}{l}{ DNA strand breaks } \\
\cline { 3 - 4 } Cells & Dexamethasone & $18 \mathrm{~h}$ & $42 \mathrm{~h}$ \\
\hline \multirow{3}{*}{ S49.1 } & 0 & rad equivalents & rad equivalents \\
& $1 \mu \mathrm{M}$ & 0 & 0 \\
S49.143R & 0 & 7 & 270 \\
& $1 \mu \mathrm{M}$ & 10 & 0 \\
& & 8 & 2
\end{tabular}

Cells were incubated with or without $1 \mu \mathrm{M}$ dexamethasone. At the indicated times, cell samples were removed and the status of their DNA evaluated in a 15-h alkaline elution procedure. The extent of DNA damage was converted to rad equivalents by comparing the amount of DNA remaining on the filter at the end of the elution period relative to a standard curve generated by treating cells with graded doses of gamma irradiation. All points were performed in duplicate. 
Table III. Effect of Exposure to $1 \mu M$ Dexamethasone

for $48 \mathrm{~h}$ on Growth and $\mathrm{NAD}^{+}$Content of

Steroid-Sensitive and Resistant Mouse Lymphoma Cells

\begin{tabular}{llll}
\hline Cell line & Dexamethasone & Cell count $\times 10^{-5}$ & $\mathrm{NAD}^{+}$pmol $/ 10^{6}$ cells \\
\hline S49.1 & 0 & 10 & 569 \\
& $1 \mu \mathrm{M}$ & 3.5 & 33 \\
S49.143R & 0 & 31 & 451 \\
& $1 \mu \mathrm{M}$ & 30 & 389
\end{tabular}

Cell cultures were incubated at $2.4 \times 10^{5}$ cells $/ \mathrm{ml}$ in the presence or absence of $1 \mu \mathrm{M}$ dexamethasone. $48 \mathrm{~h}$ later, viable cell counts were performed and cell pellets were collected for $\mathrm{NAD}^{+}$analysis. Cell counts were performed in duplicate and $\mathrm{NAD}^{+}$content was determined by duplicate assays on duplicate samples, thus all values represent the means of assays performed in quadruplicate.

with dexamethasone resulted in a $50 \%$ decrease in cell viability such that the overall culture contained $3.5 \times 10^{5}$ viable cells/ $\mathrm{ml}$, compared with $1 \times 10^{6}$ viable cells $/ \mathrm{ml}$ in control cultures. This decrease of cell viability was associated with a $94 \%$ decrease in NAD level. In contrast, $1 \mu \mathrm{M}$ dexamethasone had essentially no effect on survival of the steroid resistant S49.143R cells, and there was a $<15 \%$ difference in cellular NAD pools between control and treated cells. Thus, treatment with dexamethasone resulted in a decrease in cellular NAD levels in sensitive S49.1 cells but not in resistant S49.143R cells.

Fig. 1 shows the effect of continuous incubation in $1 \mu \mathrm{M}$ dexamethasone on the NAD level in the steroid-sensitive S49.1 cells. Whereas the NAD levels rise in the control cells, they clearly undergo a progressive depletion in the steroid-treated cells. Fig. 2 compares the relative rates of NAD, ATP, and viability loss in the S49.1 cells. In the absence of dexamethasone, the cells show a slight increase in NAD, a more marked increase in ATP levels, and viability remains constant. In the presence of $1 \mu \mathrm{M}$ dexamethasone there is a decrease in NAD, ATP, and viability. As shown in Fig. 2, depletion of NAD precedes the depletion of ATP, which in turn precedes the loss of cellular viability. These results are in agreement with the notion that steroid-induced DNA strand breaks activate poly(ADP-ribose) polymerase with consequent consumption of NAD, leading to depletion of ATP followed by loss of cell viability.

Whereas the sequences of NAD consumption followed by ATP depletion and then cell death suggest that NAD loss comes first, we also considered the possibility that the decrease in NAD

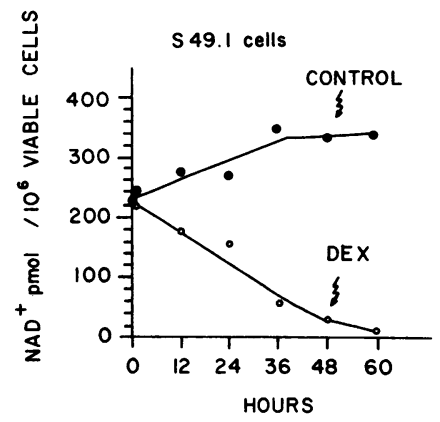

Figure 1. S49.1 cells in logarithmic growth were diluted to $2.5 \times 10^{5}$ cells $/ \mathrm{ml}$ and grown in the presence $(0)$ or absence (•) of $1 \mu \mathrm{M}$ dexamethasone. Cells were collected at the indicated time points and measurements of $\mathrm{NAD}^{+}$performed as described in Methods. All $\mathrm{NAD}^{+}$measurements were performed in duplicate on duplicate samples, thus results are presented as the means of assays performed in quadruplicate.

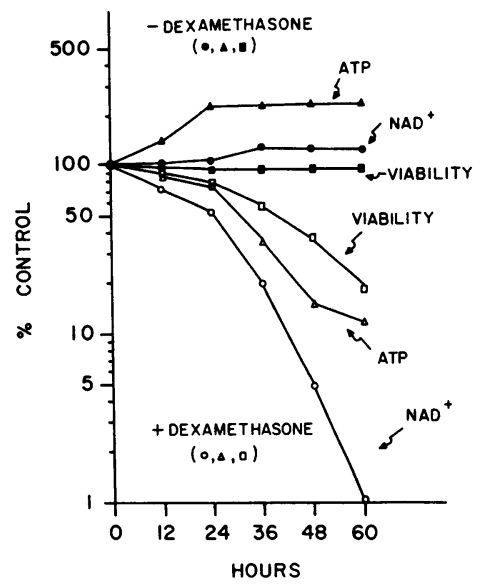

Figure 2. S49.1 cells were diluted in culture to 2.5 $\times 10^{5}$ cells $/ \mathrm{ml}$ and treated with $1 \mu \mathrm{M}$ dexamethasone (open symbols) or without dexamethasone (closed symbols). At the indicated time points cells were counted and analyzed for trypan blue exclusion, $\mathrm{NAD}^{+}$, and ATP content as described in Methods. All values are expressed as a percentage of control viability $(\square, \square), \operatorname{NAD}(0, \bullet)$, and ATP content $(\Delta, \Delta)$ at the beginning of the experiment. At 0 time, $96 \%$ of the cells excluded trypan blue, the $\mathrm{NAD}^{+}$content was $248 \mathrm{pmol} / 10^{6}$ cells and the ATP content was $935 \mathrm{pmol} / 10^{6}$ cells.

and ATP might be secondary to the decrease in viable cell numbers. To evaluate this possibility, cells were taken at various times before and after exposure to dexamethasone and centrifugal elutriation was used to prepare suspensions of cells containing predominantly dead or live cells. Intermediate fractions containing more heterogeneously distributed cell populations were not analyzed. The results are presented in Table IV. When control cells that were never exposed to steroids were elutriated and analyzed, the fraction containing the high percentage of

Table IV. Elutriation and Analysis of Dexamethasone-treated S49.1 Cells to Determine NAD and ATP Content of Viable Cells

\begin{tabular}{|c|c|c|c|}
\hline & Viability & $\mathrm{NAD}^{+}$ & ATP \\
\hline & \% total & pmol/ $10^{6} \mathrm{cells}$ & pmol $/ 10^{6} \mathrm{cells}$ \\
\hline \multicolumn{4}{|l|}{ Control } \\
\hline Unfractionated cells & 94 & 262 & 2,453 \\
\hline Elutriation fraction I & 5 & 19 & 98 \\
\hline Elutriation fraction III & 97 & 154 & 2,053 \\
\hline \multicolumn{4}{|l|}{$\begin{array}{l}1 \mu \mathrm{m} \text { dexamethasone } 24 \mathrm{~h} \\
\text { exposure }\end{array}$} \\
\hline Unfractionated cells & 81 & 88 & 1,149 \\
\hline Elutriation fraction I & 6 & 0 & 0 \\
\hline Elutriation fraction III & 96 & 102 & 1,037 \\
\hline \multicolumn{4}{|l|}{$\begin{array}{l}1 \mu \mathrm{m} \text { dexamethasone } 36 \mathrm{~h} \\
\text { exposure }\end{array}$} \\
\hline Unfractionated cells & 44 & 15.7 & 485 \\
\hline Elutriation fraction I & 8 & 0 & 0 \\
\hline Elutriation fraction III & 87 & 56.4 & 1,283 \\
\hline
\end{tabular}

S49.1 cells were treated without dexamethasone in the case of control cells or with $1 \mu \mathrm{M}$ dexamethasone for 24 or $36 \mathrm{~h}$. After the indicated treatment, a portion of the unfractionated cells was collected for $\mathrm{NAD}^{+}$and ATP assays. The cells were then fractionated by elutriation as described in Methods. Samples were taken of the fractions containing mostly dead cells (fraction I) and the fraction containing mostly live cells (fraction III). Duplicate samples from each fraction were analyzed for $\mathrm{NAD}^{+}$and ATP content. Each sample was analyzed in duplicate so that values represent the mean of measurements performed in quadruplicate. 
viable cells (fraction III) showed some decrease in NAD relative to unfractionated control cells. Similarly, there was a small decrease in ATP levels associated with the elutriation process itself. After exposure to dexamethasone, there was a significant decrease in cellular NAD content, even in the elutriated fraction containing mostly viable cells. Thus, after $36 \mathrm{~h}$ of exposure to dexamethasone, elutriation fraction III contained $87 \%$ viable cells, but the NAD content was significantly decreased relative to that in the untreated control cells. Similarly, the ATP in these viable cells was less than that in the control cells. Thus, these elutriation experiments confirmed that the decrease in cellular NAD and ATP precedes the loss of cell viability.

Tiazofurin is a synthetic nucleoside analog that is metabolized by cells into a dinucleotide analog of NAD that subsequently interferes with maintenance of cellular NAD levels (17). Because our studies suggest that dexamethasone cytotoxicity involves NAD depletion, we reasoned that combined treatment of cells with tiazofurin and dexamethasone might produce a more rapid cytotoxic effect by interfering with synthesis as well as increasing consumption of NAD. Fig. 3 shows that tiazofurin alone slowed the growth rate of S49 cells, whereas dexamethasone resulted in a decrease in cell number. The combination of dexamethasone and tiazofurin produced a more rapid kill than either agent alone.

In the course of these studies we had the opportunity to examine cells from a patient with chronic lymphocytic leukemia to determine whether glucocorticoid-induced cell killing is mediated by a similar phenomenon in human cells. Because of the large numbers of cells required and because of the general resistance of normal lymphocytes to steroid-induced cell killing, similar studies were difficult to perform in normal human lymphocytes. Table $\mathrm{V}$ shows that the lymphocytes from the CLL patient showed DNA strand breaks equivalent to $105-110$ rads even without exposure to glucocorticoids. These breaks were not associated with chemotherapy, because the patient was untreated. They may well reflect a characteristic of CLL cells, and further studies will be required to evaluate this possibility. Upon exposure to dexamethasone, the CLL cells showed the slow accumulation of DNA strand breaks with $1 \mu \mathrm{M}$ dexamethasone producing 217 rad equivalents of DNA strand breaks after $6 \mathrm{~d}$ exposure. Because these data were obtained with CLL cells derived from one individual, it is possible that the number and rate of development of strand breaks will vary in the cells from different patients.

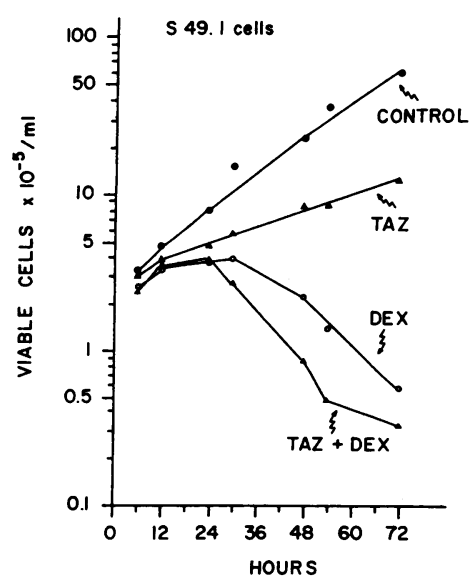

Figure 3. S49.1 cells in logarithmic growth were diluted to $2.5 \times 10^{6}$ cells $/ \mathrm{ml}$ and grown in the presence of no additions for control cells (๑), $1 \mu \mathrm{M}$ tiazofurin (৯), $1 \mu \mathrm{M}$ dexamethasone (o), or $1 \mu \mathrm{M}$ tiazofurin plus $1 \mu \mathrm{M}$ dexamethasone $(\Delta)$. Cell counts and trypan blue exclusion were determined at the indicated time points. Viable cells represent the total number of cells corrected for the percent capable of excluding trypan blue.
Table V. Glucocorticoid-induced DNA Strand

Breaks in Human CLL Lymphocytes

\begin{tabular}{lll}
\hline & \multicolumn{2}{l}{ DNA strand breaks } \\
\cline { 2 - 3 } Dexamethasone & Day 3 & Day 6 \\
\hline & rad equivalents & rad equivalents \\
0 & $110( \pm 10)$ & $110( \pm 10)$ \\
$0.1 \mu \mathrm{M}$ & $112( \pm 12)$ & $135( \pm 15)$ \\
$1 \mu \mathrm{M}$ & $155( \pm 5)$ & $217( \pm 7)$ \\
\hline
\end{tabular}

Lymphocytes from a patient with CLL were incubated with different concentrations or no dexamethasone in complete tissue culture medium at $37^{\circ} \mathrm{C}$. At the indicated times, cells were removed from culture and DNA strand breaks determined by alkaline elution. Damage is expressed as rad equivalents by comparison to a standard curve generated by analysis of cells treated with graded doses of gamma irradiation. Results are presented as the mean $( \pm \mathrm{SE})$ of assays performed in duplicate.

Table VI shows the effect on nucleotide pools of chronically exposing CLL cells to glucocorticoids. The initial level of NAD and ATP in the human CLL cells was significantly lower than in the mouse cells. This is characteristic of a nonreplicating cell population and has been previously described $(12,15)$. Incubation of the cells in tissue culture medium resulted in preservation of nucleotide pools and viability. However, when the cells were exposed to $10^{-6} \mathrm{M}$ dexamethasone, there was a decrease in NAD and ATP followed by loss of cell viability. Thus, the CLL cells resemble the mouse cells in that a decrease in NAD and ATP occurs as a precursor to cell death. This is further supported by the results with $10^{-8} \mathrm{M}$ dexamethasone where the changes occur more slowly and clearly demonstrate that the metabolic pool changes precede the loss of cell viability.

\section{Discussion}

Considerable evidence exists to demonstrate that steroid-induced cytotoxicity in susceptible lymphoid cells is associated with nuclear fragmentation and chromosomal breakage $(3,4)$, presumably due to the induction of endogenous nuclease activities (18). Whereas these alterations are expected to interfere with cell replication, the mechanism by which they lead to cell death has not been clearly defined. We have recently shown that mutagens and carcinogens that damage DNA can lead to cell death in an indirect manner as a consequence of metabolic changes initiated in response to DNA damage $(5,6)$. Thus, DNA strand breaks lead to the activation of poly(ADP-ribose) polymerase, which utilizes NAD for the synthesis of homopolymers of repeating ADP-ribose units. Synthesis of this polymer presumably functions in the DNA repair process (19). However, when the enzyme is activated by high levels or persistent DNA strand breaks, it can totally consume NAD pools, resulting in a loss of ability to synthesize ATP, cessation of all energy dependent functions and consequent cell death $(5,6)$. Thus, the metabolic effects that occur as a consequence of DNA damage can kill cells independently of the direct effects on DNA function $(5,6,9,20)$. This pathway provides a mechanism by which DNA strand breaks can lead to cell death in replicating and in resting intermitotic cells as well. In addition, it provides a fail-safe mechanism to eliminate cells with such extensive DNA damage that survival would probably be accompanied by very high mutation rate. 
Table VI. Effect of Dexamethasone on NAD and ATP Levels in Human CLL Cells

\begin{tabular}{|c|c|c|c|c|c|c|c|c|c|}
\hline \multirow[b]{2}{*}{ Day } & \multicolumn{3}{|l|}{ Control } & \multicolumn{3}{|c|}{$1 \mu \mathrm{M}$ dexamethasone } & \multicolumn{3}{|c|}{$0.01 \mu \mathrm{M}$ dexamethasone } \\
\hline & $\%$ Viable & $\mathrm{NAD}^{+}$ & ATP & $\%$ Viable & $\mathrm{NAD}^{+}$ & ATP & $\%$ Viable & $\mathrm{NAD}^{+}$ & ATP \\
\hline 0 & 98 & 48.3 & 494 & & & & & & \\
\hline 1 & 97 & 69.2 & 521 & 97 & 54.0 & 424 & 97 & 56.7 & 393 \\
\hline 2 & 98 & 66.8 & 481 & 95 & 32.4 & 271 & 94 & 49.9 & 363 \\
\hline 3 & 97 & 72.7 & 526 & 90 & 18.6 & 159 & 100 & 42.5 & 302 \\
\hline 4 & 100 & 57.5 & 465 & 81 & 18.2 & 185 & 97 & 31.4 & 302 \\
\hline 5 & 98 & 65.1 & 465 & 59 & 12.9 & 115 & 80 & 25.0 & 217 \\
\hline 6 & 94 & 59.2 & 446 & 48 & 8.5 & 87 & 74 & 13.1 & 119 \\
\hline 7 & & 49.0 & 438 & & 3.5 & 32 & & 18.0 & 40 \\
\hline 8 & 90 & 42.3 & 411 & 28 & 0 & 2.4 & 48 & 0 & 32 \\
\hline 9 & 82 & 36.7 & 356 & 27 & 0 & 0 & 48 & 0 & 12 \\
\hline
\end{tabular}

Peripheral blood lymphocytes were prepared from a patient with CLL who had received no cytotoxic chemotherapy. The cells were incubated at 3 $\times 10^{5} / \mathrm{ml}$ in complete tissue culture medium in the absence or presence of 0.01 or $1 \mu \mathrm{M}$ dexamethasone. Studies were performed at daily intervals. Viability was determined by trypan blue exclusion. Values for NAD ${ }^{+}$and ATP are expressed as pmol/10 $0^{6}$ cells. Values of 0 mean that no $\mathrm{NAD}^{+}$or ATP was detected when the lower limit of detection was $1 \mathrm{pmol} / 10^{6}$ cells. All assays were performed in duplicate on duplicate samples.

In the present study we have shown that activation of the poly(ADP-ribose) polymerase pathway appears to be involved in steroid-mediated cytotoxicity in susceptible mouse lymphoma cells as well as in human CLL cells. All of these cells were shown to have the enzyme poly(ADP-ribose) polymerase and the enzyme was shown to increase in activity in response to DNA strand breaks. Whereas all the cells have poly(ADP-ribose) polymerase capable of responding to DNA damage, NAD depletion occurred in the susceptible S49.1 cells but not in the resistant S49.143R cells. Thus, the steroid-induced DNA strand breaks and associated NAD and ATP depletion correlates with the known susceptibility and resistance of these cells to steroid-induced cytotoxicity. These cells are known to be sensitive or resistant to glucocorticoids on the basis of structural alterations in their steroid receptors $(1,2)$. Thus, the initial effect of the glucocorticoids appears to be mediated through the steroid receptor and the dexamethasone does not appear to directly activate poly(ADP-ribose) polymerase. Rather, it appears that the dexamethasone binds to its receptor, which then initiates a process leading to DNA strand breaks. Our results in the susceptible mouse lymphocytes indicate that the DNA strand breakage occurs very slowly during the first $24 \mathrm{~h}$ and then rapidly increases during the next $24 \mathrm{~h}$. After $42 \mathrm{~h}$ exposure to $10^{-6} \mathrm{M}$ dexamethasone, the susceptible cells showed DNA strand breakage equivalent to that produced by 270 rad gamma radiation. These DNA strand breaks are presumably more toxic than those created by radiation because the continuous exposure to steroids results in breaks that are persistent and cumulative (4), whereas radiationinduced breaks are rapidly repaired (16). The appearance of these strand breaks and the sequential depletion of NAD, ATP, and subsequent decrease in cell viability are consistent with the proposal that persistent steroid-induced DNA strand breaks lead to the activation of poly(ADP-ribose) polymerase as a final pathway leading to cell death. Studies with lymphocytes from a patient with chronic lymphocytic leukemia also demonstrate the increase in steroid-induced DNA strand breaks, as well as the depletion of NAD and ATP and consequent loss of cell viability. These studies clearly show that this pathway is activated at doses as low as $10^{-8} \mathrm{M}$ dexamethasone, which is well within the pharmacological range where this agent is used therapeutically.

In previous experiments, using direct-acting DNA-damaging agents to activate poly(ADP-ribose) polymerase-mediated depletion of NAD and ATP pools, we showed that competitive inhibitors of this enzyme, such as 3-aminobenzamide, could delay polymer synthesis by $\sim 15 \mathrm{~min}$ but could not prevent the nucleotide pool depletion $(5,9,20)$. In the present study, using agents such as 3-aminobenzamide or nicotinamide, we were unable to sufficiently interfere with poly(ADP-ribose) synthesis to retard the process of nucleotide depletion and cell death. However, this is not unexpected because an agent that retards a process by $\sim 15$ min would not be expected to have any detectable effect on a process that occurs over several days.

These studies demonstrate that steroid-induced cell death in susceptible mouse and human lymphocytes is associated with a process in which DNA strand breaks and NAD and ATP depletion occur as a precursor leading to cell death. This process should not be confused with the immunosuppressive effect of steroids. Obviously, steroid-induced cell death would interfere with the ability of the dead lymphocyte to participate in the immune response. However, it has been shown recently that steroids can interfere with the immune response by inhibiting production of leukotriene $\mathrm{B}_{\mathbf{4}}$ in mitogen-stimulated lymphocytes (21). Thus, interference with arachidonic acid metabolism may produce a pathway for inhibiting the immune response without causing cell death.

The mechanism that we have proposed for poly(ADP-ribose) polymerase-mediated cell death appears to constitute a final common pathway by which many physiologic and toxic processes may lead to cell death. We have previously shown that this pathway accounts for the rapid cell death that occurs when cells exposed to oxidant injury (22) and in lymphocytes exposed to chlorodeoxyadenosine, deoxyadenosine, and deoxycoformycin (23). It is interesting to note that both normal human B lymphocytes as well as chronic lymphocytic leukemia cells are more sensitive than $\mathrm{T}$ lymphocytes to hydrogen peroxide toxicity (24). Because the effect of oxidant injury and corticosteroid tox- 
icity both appear to be mediated through induction of DNA strand breaks and activation of poly(ADP-ribose) polymerase, it is possible that the susceptibility of CLL cells to corticosteroids reflect a metabolic characteristic of the $B$ cell lineage rather than an unusual characteristic of the malignant cell population.

The pathway of DNA strand breaks leading to activation of poly(ADP-ribose) polymerase, nucleotide depletion, and consequent cell death provides a mechanism to explain the interphase death that occurs in nonreplicating lymphocytes exposed to a variety of DNA-damaging agents; it has also been proposed to contribute to the programmed cell death that occurs in the lymphoid system (25). Recognition of this pathway as a mechanism of cell death suggests that different agents activating poly(ADP-ribose) polymerase or interfering with pyridine nucleotide metabolism may have synergistic, cytotoxic effects. We have shown in this manuscript that a combination of tiazofurin, which interferes with NAD synthesis, and dexamethasone, which causes depletion of NAD pools, produces more rapid cell death than either agent alone. Similar combinations of agents that focus on depletion of cellular pyridine nucleotide pools may be useful in treating human diseases such as chronic lymphocytic leukemia.

\section{Acknowledgments}

This research was supported by National Institutes of Health grants CA42755, CA-35983, and GM-32647. Some of the studies were performed in facilities supported by the Sohio Foundation.

\section{References}

1. Baxter, J. D., A. W. Harris, G. M. Tomkins, and M. Cohn. 1971. Glucocorticoid receptors in lymphoma cells in culture: relationship to glucocorticoid killing activity. Science (Wash. DC). 171:189-191.

2. Yamamoto, K. R., U. Gehring, M. R. Stampfer, and C. H. Sibley. 1976. Genetic approaches to steroid hormone action. Recent Prog. Horm. Res. 32:3-32.

3. Wyllie, A. H. 1980. Glucocorticoid-induced thymocyte apoptosis is associated with endogenous endonuclease activation. Nature (Lond.). 284: 555-556.

4. Compton, M. M., and J. A. Cidlowski. 1986. Rapid in vivo effects of glucocorticoids on the integrity of rat lymphocyte genomic deoxyribonucleic acid. Endocrinology. 118:38-45.

5. Sims, J. L., S. J. Berger, and N. A. Berger. 1983. Poly(ADP-ribose) polymerase inhibitors preserve $\mathrm{NAD}^{+}$and $\mathrm{ATP}$ pools in DNA-damaged cells: mechanism of stimulation of unscheduled DNA synthesis. Biochemistry. 22:5188-5194.

6. Berger, N. A. 1985. Poly(ADP-ribose) in the cellular response to DNA damage. Radiat. Res. 101:4-15.

7. Berger, N. A., G. Weber, and A. S. Kaichi. 1978. Characterization and comparison of poly(adenosine diphosphoribose) synthesis and DNA synthesis in nucleotide-permeable cells. Biochim. Biophys. Acta. 519: 87-104.

8. Hayaishi, O., and K. Ueda. 1977. Poly(ADP-ribose) and ADP ribosylation of proteins. Annu. Rev. Biochem. 46:95-116.

9. Berger, S. J., D. C. Sudar, and N. A. Berger. 1986. DNA damage induces alterations in glucose metabolism by activation of poly(ADPribose) polymerase. Biochem. Biophys. Res. Commun. 134:227-232.

10. Distelhorst, C. W., B. M. Benutto, and R. A. Bergamini. 1984. Effect of cell cycle position on Dexamethasone binding by mouse and human lymphoid cell lines: correlation between an increase in Dexamethasone binding during $S$ phase and Dexamethasone sensitivity. Blood. 63:105-113.

11. Berger, N. A., J. W. Adams, G. Weber, S. J. Petzold, and W. T. Shearer. 1978. Synthesis of DNA and poly(adenosine diphosphoribose) in normal and CLL lymphocytes. J. Clin. Invest. 62:111-118.

12. Berger, N. A., S. J. Berger, G. W. Sikorski, and D. M. Catino. 1982. Amplification of pyridine nucleotide pools in mitogen stimulated human lymphocytes. Exp. Cell Res. 137:79-88.

13. Kohn, K. W., L. C. Erickson, R. A. G. Ewig, and C. A. Friedman. 1976. Fractionation of DNA from mammalian cells by alkaline elution. Biochemistry. 15:4629-4637.

14. Meyn, R. E., and W. T. Jenkins. 1983. Variation in normal and tumor tissue sensitivity of mice to ionizing radiation-induced DNA strand-breaks in vivo. Cancer Res. 43:5668-5673.

15. Sweigert, S. E., S. J. Petzold, C. S. Surowy, S. J. Berger, L. A. Dethlefsen, and N. A. Berger. 1986. Poly(ADP-ribose) polymerase activity in proliferating and quiescent murine mammary carcinoma cells. Radiat. Res. 105:219-226.

16. Zwelling, L. A., D. Kerrigan, and Y. Pommier. 1982. Inhibitors of poly-(adenosine diphosphoribose) synthesis slow the resealing rate of $\mathrm{x}$-ray-induced DNA strand breaks. Biochem. Biophys. Res. Commun. 104:897-902.

17. Berger, N. A., S. J. Berger, D. M. Catino, S. J. Petzold, and R. K. Robins. 1985. Modulation of nicotinamide adenine dinucleotide and poly(adenosine diphosphoribose) metabolism by the synthetic " $\mathrm{C}$ " nucleoside analogs, tiazofurin and selenazofurin. J. Clin. Invest. 75:702709.

18. Cohen, J. J., and R. C. Duke. 1983. Glucocorticoid activation of a calcium-dependent endonuclease in thymocyte nuclei leads to cell death. J. Immunol. 132:38-42.

19. Durkacz, B. W., O. Omidiji, D. A. Gray, and S. Shall. 1980. (ADP-ribose) $n$ participates in DNA excision repair. Nature (Lond.). 283: 593-596.

20. Berger, N. A., and S. J. Berger. 1986. Metabolic consequences of DNA damage: the role of poly(ADP-ribose) polymerase dependent and independent processes. Biochem. Biophys. Res. Commun. 136:11531158.

21. Goodwin, J. S., D. Atluru, S. Sierakowski, and E. A. Lianos. 1986. Mechanism of action of glucocorticosteroid. Inhibition of T cell proliferation and interleukin 2 production by hydrocortisone is reversed by leukotriene $\mathrm{B}_{4}$. J. Clin. Invest. 77:1244-1250.

22. Schraufstatter, I. U., D. B. Hinshaw, P. A. Hyslop, R. G. Spragg, and C. G. Cochrane. 1986. Oxidant injury of cells. J. Clin. Invest. 77: 1312-1320.

23. Seto, S., C. J. Carrera, M. Kubota, D. B. Wasson, and D. A. Carson. 1985. Mechanism of deoxyadenosine and 2-chlorodeoxyadenosine toxicity to nondividing human lymphocytes. J. Clin. Invest. 75: 377-383.

24. Farber, C. M., L. F. Liebes, D. N. Kanganis, and R. Silber. 1984. Human B lymphocytes show greater susceptibility to $\mathrm{H}_{2} \mathrm{O}_{2}$ toxicity than T lymphocytes. J. Immunol. 132:2543-2546.

25. Carson, D. A., S. Seto, D. B. Wasson, and C. J. Carrera. 1986. DNA strand breaks, NAD metabolism and programmed cell death. Exp. Cell Res. 164:273-281. 